al-Ihkam: Jurnal Hukum dan Pranata Sosial, 15 (1), 2020: 1-30

ISSN: 1907-591X, E-ISSN: 2442-3084

DOI: http:/ / doi.org/10.19105/al-ihkam.v15i1.2689

\title{
State Marriage and Civil Marriage: The Role of State Policy on Interreligious Marriage in Central Java
}

\author{
Anthin Lathifah \\ Faculty of Shari' a and Law, State Islamic University Walisongo, Jl. \\ Walisongo No.3-5, Tambakaji, Kec. Ngaliyan, Kota Semarang, \\ Jawa Tengah 50185 \\ Email:anthin_lathifah@walisongo.ac.id
}

Article history: Received: 28 October 2019, Accepted: 27 Februari 2020, Published: 27 Juni 2020

\begin{abstract}
:
This article discusses interreligious marriage phenomenon in Central Java particularly in in Surakarta, Semarang and Jepara where policies of stakeholders on judicial system as well role of demographic officials and religious leaders heavily influence each other. Interestingly, the policies of State Court as authorized institution to legalize interreligious marriage vary among those three. The Surakarta State Court receives petition and allows interreligious marriage in contrast to Semarang and Jepara which deny this kind of petition. This difference comes from several factors, namely understanding of Indonesian marriage laws, religious understanding and role of religious leaders. In the context of state and civil society relations, interreligious couples whose petitions are rejected consider it unfair, while those with accepted petition also deem it the same since they consider their marriage as a civil marriage only which the state does not wish.
\end{abstract}

\section{Keywords:}

Interreligious Marriage; Civil Marriage; State Policy; Civil

$$
\text { Rights }
$$

Author correspondence email: anthin_lathifah@walisongo.ac.id Available online at: http:/ / ejournal.iainmadura.ac.id/index.php/alihkam/ Copyright (c) 2020 by al-ihkam. All Right Reserved 


\begin{abstract}
Abstrak:
Artikel ini membahas tentang perkawinan beda agama di Jawa Tengah, khususnya di Surakarta, Semarang dan Jepara, tempat-tempat di mana kebijakan para pemangku kepentingan tentang sistem peradilan, peran pejabat demografik dan pemimpin agama saling mempengaruhi satu sama lain. Kebijakan Pengadilan Negeri sebagai lembaga yang berwenang menentukan perkawinan beda agama bervariasi dari satu daerah dengan daerah yang lain. Pengadilan Negeri Surakarta menerima petisi dan menetapkan perkawinan beda agama, berbeda dengan Pengadilan Negeri Kota Semarang dan Kabupaten Jepara yang menolak permohonan perkawinan beda agama. Perbedaan kebijakan tersebut dipengaruhi oleh beberapa hal, yaitu pemahaman tentang peraturan perundangundangan perkawinan di Indonesia, pemahaman agama dan peran para pemimpin agama. Dalam konteks hubungan negara dan masyarakat sipil, pasangan antaragama yang permohonannya ditolak menganggapnya tidak adil; bahkan mereka yang permohonannya diterima juga menganggap itu tidak adil karena mereka menganggap perkawinannya hanyalah perkawinan sipil yang tidak diinginkan oleh negara.
\end{abstract}

\title{
Kata Kunci:
}

Pernikahan Beda Agama; Pernikahan Sipil; Kebijakan Negara; Hak Sipil

\section{Introduction}

Confirming validity of a marriage, Article 2 paragraph (1) of Marriage Law No. 1 of 1974 states that "marriage is lawful in accordance with religion and belief respectively". ${ }^{1}$ Furthermore, the implemented regulation of marriage law called the Implementation of

${ }^{1}$ During the New Order, the recognized religions are Islam, Catholicism, Protestantism, Hinduism and Buddhism as stated on Presidential Instruction No. 14/1967 and the Decision of the Minister of Home Affairs in 1978. However, President Abdurrahman Wahid retracted both instruction and issued the Decree No. 6 of 2000 which recognized Confucianism as a religion. Therefore, the recognized religions in Indonesia now are six namely Islam, Christianity, Protestantism, Hinduism, Buddhism and Confucianism. 
Regulation (Peraturan Pelaksanaan/PP) No. 9 of 1975 Article 10, paragraph (2) explains that "marital procedure is done according to the law of each religion and belief". This provision applies to all religions in Indonesia except Islam since it combines the law with the provisions of Compilation of Islamic Law (Kompilasi Hukum Islam/KHI).

For Muslims, Article 4 of Compilation of Islamic Law indicates that their marriage can be valid "if it is done according to Islamic law in accordance with article 2, paragraph (1) of Law No. 1 of 1974 on Marriage." Although Compilation of Islamic Law does not normatively mention the terms of Muslims for the groom and the bride, Indonesian ulemas in general require that both of them must be Muslim $^{2}$ although some of them allow Muslims to do interreligious marriage with non-Muslim. ${ }^{3}$

Normatively, the Compilation of Islamic Law prohibits interreligious marriage both between a Muslim man with a nonMoslem woman (article $40 \mathrm{KHI}$ ) and a Moslem woman with a nonMoslem man (article $44 \mathrm{KHI}$ ). Likewise, the Indonesian ulema mostly require bride and groom to be Muslim, ${ }^{4}$ although some were of the opinion that Muslim and non-Muslim marriages could be performed based on the permissible marriage of Muslim men and women of the book. ${ }^{5}$ Even administratively, Muslim and non-Muslim marriages are

\footnotetext{
${ }^{2}$ See the opinion of Ahmad Rofiq, Hukum Perdata Islam Indonesia (Jakarta: Raja Grafindo Persada), 2011. Similarly, the Fatwa of Indonesian Ulema Council No. 4 / Munas VII / MUI / 8/2005 in National Conference VII in 2005 contains as follow: 1. Interreligious marriage is unlawful and invalid; 2. Marriage of Muslim men with women of ahli kitab (people of the book) according to qaul mu'tamad is unlawful and invalid.

${ }^{3}$ Both Nurcholis Majid and Musdah Mulia allow interreligious marriage based on Surah al-Maidah: 3 that clearly allows Muslim to marry People of the book and does not prohibit marriage with them. For them, provision of marriages with non-Muslims is in the area of ijtihad that depends on the context. See Mun'im Sirry A. (Ed.) Fikih Lintas Agama; Membangun Masyarakat Inklusif-Pluralis (Jakarta: Paramadina, 2004),. 164.

4The Decree of The Indonesian Ulema Fatwa Council No. 4/ National Conference VII/MUI/8/2005 stipulated in the VII National Conference in 2005 contains as follows: 1. Interfaith marriages are haram and illegitimate; 2 . The marriage of Muslim men to ahl kitab women, according to qaul mu'tamad is haram and illegal.

${ }^{5}$ As Nur Cholis Majid argues, Musdah Mulia who permits interfaith marriages is based on QS al-Maidah: 3 which directly permits Muslim marriages with Ahli Kitab
} 
regulated in the Law No. 23 of 2006 concerning population administration.

Using those provisions, the state only recognizes marriages as legally governed by state-recognized religions; Islam, Catholicism, Protestantism, Hinduism, Buddhism and Confucianism6. Similarly, the state explicitly has no statement on the provisions of interreligious marriage unless prior to the Marriage Law No. 1 of 19747 although administratively, it sets its provisions in Law No. 23 of 2006 on the demographic administration.

Such circumstances, according to Ratno Lukito, ${ }^{8}$ indicate the fact that since 1974, there was no definitive law on marriage between men and women of different religions in Indonesia and consequently, there exists legal vacuum condition. Relating to this, Mark Cammack ${ }^{9}$ commented that in Indonesia, there is no legalized marriage for different religion so that this kind of marriage cannot be performed in Indonesia.

In the context of state's obligation to provide legal rights to its citizens, the void of interreligious marriage regulation becomes a problem since it contrasts to article 27 of the Constitution of 1945 which concedes that every citizen is equal before the law. Similarly, Article 28B of the Constitution states that "everyone has rights to build

and in essence does not prohibit marriages with Ahli Kitab. For them, the terms of marriages with non-Muslims are ijtihadi areas which depend on the context. See Mun'im A. Sirry (Ed.) Fikih Lintas Agama; Membangun Masyarakat Inklusif-Pluralis (Jakarta: Paramadina, 2004), 164.

In the New Order government, government-recognized religion is Islam, Catholicism, Protestantism, Hinduism and Buddhism, as a presidential instruction No. 14/1967 and decision of the Minister of the Interior in 1978. However, president Abdurrahman Wahid retracted instruction and replaced it by Decree No. 6 of 2000 which recognized Confucianism as a religion, so the recognized religions in Indonesia there are six namely Islam, Christianity, Protestantism, Hinduism, Buddhism and Confucianism.

${ }^{7}$ Before the Law of Marriage No. 1 of 1974 dan Impelementation Regulation No. 9 of 1975, interreligious marriage has been governed on Staatsblad 1898 No. 158 and was categorized into mixed marriage.

8Ratno Lukito, Hukum Sakral dan Hukum sekuler Studi tentang Konflik dan Resolusi Sistem Hukum di Indonesia (Jakarta: Pustaka Alvabet, 2008),. 420-429

${ }^{9}$ Mark Cammack, Legal Aspect of Muslim-Non Muslim Marriage in Indonesia, in Gavin Willis et.al (Ed.) Muslim-Non Muslim Marriage: Political and Cultural Contestation in Southeast Asia (Singapore: ISEAS Publishing, 2009),. 102-103. 
a family and continue their descendants through a legal marriage." It also contrasts to Law No. 39 of 1999 on Human Rights in article 10 paragraph (1) which describes "everyone has the rights to build a family and continue their descendants through legitimate marriage and free will". This contoversy even leads to a judicial review of Law No. 1 of 1974 Article 2 paragraph (1) submitted to the Constitutional Court with registration number 68/PUU-XII/2014, although the Constitutional Court finally rejected the petition on the reason that the Marriage Law does not violate the Constitution. ${ }^{10}$

Therefore, not only does this problem trigger formal and legal issues in which marriage validity depends on its accordance with provisions of religious and administrative systems, but also pose a political problem on whether the citizens' rights to perform a marriage depends on policy makers. From the perspective of state policy and the rights of civil society, this paper will examine how interreligious marriages occur in a practical level as a result of legal policy of stakeholders in Central Java namely at Surakarta, Semarang and Jepara.

\section{Concepts on Legal Policy and Legal Justice}

The word "policy" etimologically originates from English word "policy" or Dutch word "politiek". Terminologically, policy means a set of concepts or principles which form the basis for doing a job, leadership and how to behave. ${ }^{11}$ Thus, the phrase of legal policy is synonymous with political law. Mahfudh furthermore says that political law is also a legal policy or legal direction that the state needs to enforce it in order to achieve its purposes by either creating a new law or replacing the old one. ${ }^{12}$

Meanwhile, Klein explains that policy is a conscious and systematic action using the ways that pursues political purposes. According to Carl J Fredrick ${ }^{13}$, policy is an action proposed by

\footnotetext{
10See the decision of Judicial Review on reviewing Law No. 1 of 1974 on Marriage towards the Constitution of 1945 on case No. 68/PUU-XII/2014.

11See Hoorgerwerf, "Isi dan Corak-Corak Kebijakan" as cited by Adang Yesmil Anwar, Pembaruan Hukum Pidana; Reformasi Hukum (Jakarta: Grasindo, 2008),. 57.

12Moh. Mahfudh MD, Membangun Politik Hukum, Menegakkan Konstitusi (Jakarta: Rajawali Press, 2011), 5

13See Klein and Carl J Fredrick as cited by Adang Yesmil Anwar, Pembaruan..., 57.
} 
someone, a group or a government in a particular condition by showing the obstacles and opportunities to implement its proposed policy in order to achieve its certain goals.

According to Birkland, ${ }^{14}$ furthermore, the policy process is often associated with public policy that resembles several characteristics, namely: a) is created to respond some short problems that require attention, b) should be made for the sake of public interest, c) is oriented to national goals or interests as well as to solve problems, d) is ultimately made by the government although the idea might originate from the party outside of the government or as a result of interaction between government and non-government actors, e) is interpreted and implemented by community and people with different interpretations about the problems, solutions and motivation, and f) is a choice for the government to implement or avoid it. Birkland ${ }^{15}$ also explains that a policy may be a law or a regulation or a set of laws or rules that become an issue and problem for a government.

According to Satjipto Rahardjo, ${ }^{16}$ politic of law is an activity and a way to choose what to use in order to achieve certain social and legal objectives in the community. There are some fundamental questions in the study of the politics of law as follow: First, what are the goals to be achieved through the existing system?; Second, what and which ways are considered the best to use in achieving those objectives?; Third, when and how does the law need to change?; Fourth, may a standard and well-established pattern be formulated to assist in deciding the process of goal's selection as well as the way to achieve that goals? Thus, legal policy is a complete system of performance that involves the understanding and knowledge of its enforcers to operate and to enforce its provision by considering the sense of justice and benefit for society.

In addition, it is a policy which determines whether a legal or regulated provisions are strongly influenced by knowledge and

14Thomas A. Birkland, Introduction to the Policy Procces; Theory, Concepts and Models of Public Policy Making (New York: M.E. Sharpe. Inc, vol.3, 2011),. 8-9

${ }^{15}$ Thomas A. Birkland, Introduction to the Policy Procces, 9.

16See Sartjipto Raharjo's opinion as cited by Moh. Mahfudh, Membangun Politik Hukum...., 14. 
interests of its enforcement. Dery ${ }^{17}$ said that analysis of a policy heavily relies on political process. Whether a policy might become a social problem or not, it depends on the agendas formulated through political processes.

In a similar tone, Yesmil Anwar ${ }^{18}$ argues that the issues of legal policy are closely related to the integrity of law enforcement and its problems which can be politics, social or religious. It means that policy of law enforcement to determine solutions to the problems of law describes the range in which power of law enforcement runs towards a legal policy.

Relating to this, Mahfudh ${ }^{19}$ explains that each legal policy is a product of political decisions and therefore in the reality (das sein), law manifests a crystallization of political thought among the stakeholders who interact each other and implying a correlation between the character of every legal product with the policies of political stakeholders. A democratic person will produce responsive or populistic laws, whereas an authoritarian will create orthodox or conservative legal policies. ${ }^{20}$ It is contingent with Marzuki Wahid ${ }^{21}$ who calls the Marriage Law No. 1 of 1974 as a political product of New Order or a school of Figh Negara (Figh State). Similarly, William Liddle $^{22}$ names it Soeharto Law for legal policies and its all political institutions created during Soeharto era.

In this sense, Foucault ${ }^{23}$ also explains that the legal system and court are fields which are definitely linked with domination and power through subjugation. According to him, a law should not be shown by its established legitimacy, though in reality, it is always a process of conquest.

17David Dery, Problem Definition in Policy Analiysis, Kansas: University Press of Kansas, 1984,. 5.

18See understanding the context on Adang Yesmil Anwar, Pembaruan Hukum Pidana,. 58.

${ }^{19}$ Moh. Mahfudh MD, Pergulatan Politik dan Hukum di Indonesia, Yogyakarta: Gama Media, 1999, 4

20Moh. Mahfudh, Pergulatan Politik dan Hukum di Indonesia,. 80

${ }^{21}$ Marzuki Wahid and Rumadi, Fiqh Madzhab Negara Kritik atas Politik Hukum Islam di Indonesia (Yogyakarta: LKiS, 2001).

${ }^{22}$ R. William Liddle, "Soeharto's Indonesia; Personal Rule and Political Institutions", in Pacific Affairs, Vol. 58, No. 1 (Spring, 1985), 78 .

${ }^{23}$ Michael Foucoult, Society Must be Defended (New York: Martin Press, 2003). 
Rawls ${ }^{24}$ however says that a just law must be based on fairness and a sense of justice for the public, while one's obedience to the law determines to what extent the laws, institutions and policies are just. Not only be normative, justice is also at the level of procedural fairness. Rawls then proposes a distributive justice implying that justice must be distributed to all citizens of both majority and minority, although in the context of the differences between the majority and the minority, the first is more preferred based on the Rawls' principle on utilitarianism.

Thus, the knowledge and interests of each maker of law enforcement and its enforcer determine the birth of a law, though in the ideal level, it should aim to uphold public justice. In this sense, law enforcement in Indonesia also should normatively have the authority to determine law using the sense of justice.

\section{The Rights of Civil Society}

Mahfudh ${ }^{25}$ says that neither Islamic nor secular, Indonesia is a state based on Pancasila (Five Pillars). It is thus impossible to govern rules on civil society by Islam or other religion. In reality, however, the state regulates issues related to religious communities, including the issue of marriage. It, for instance, regulates the validity of marriage based on provisions of official religion in Indonesia, which is limited only to six religions.

The problem arises when the policy of interreligious marriage which is not regulated in Indonesian marriage law seems contradictory to the national constitution, namely the 5th pillar of Pancasila on "social justice for all Indonesian people." Furthoremore, it is also contrary to the Constitution of 1945 section $28 \mathrm{~B}$ which mentions the rights of citizens to establish a family and Law No. 39 of 1999 on Human Rights article 10 paragraph (1) which writes that "every person has the rights to build a family and continue their descendants through legitimate marriage and free will."

\footnotetext{
${ }^{24}$ John Rawls, A Theory of Justice, The Theory of Justice (United States of America: Harvard University Press, 2003).

${ }^{25}$ Moh. Mahfud MD, Membangun Politik Hukum Menegakkan Konstitusi (Jakarta: PT. Raja Grafindo persada, 2011),. 281.
} 
This becomes both problematic and contradictive because the state provides freedom and rights for every citizen to build a family and continue their descendants while on the other side, this permission is constrained by the provisions of the marriage law. It is also contradictive because according to the concept of Hans Kelsen on the Stufen theory,26 law should be a hierarchy, where the legal provisions of marriage law must follow the provisions from the higher existing law. It becomes more contradictive since the state only considers a marriage valid when its settlement is performed and registered under one of the official religions namely Islam, Catholicism, Protestantism, Buddhism, Hinduism and Confucianism, which in fact is a legal product of governments laden with political interests.

According to Yudi Latif, Moh. Hatta and Supomo formulated the concept of the state and its obligations in providing protection to the citizens and their principal rights including civil and political rights such as national and social freedom (article 29 of the amended Constitution of 1945) and rights to get equality before law and government (article 27 paragraph(1). In fact, in addition to both rights, every citizen also has rights to social, economy and culture as accommodated in the Act of 1945. It also includes rights to work and to make a good living (article 27 paragraph 2), to defend the state (article 31 paragraph 1), to get education (article 31 paragraph 1), as well as economic rights and welfare (for the poor) in article 33 and $34 .{ }^{27}$

Furthermore, Latif classified those rights into three, namely civil and political rights, democratic rights and socio-economic-cultural as well as collective rights. ${ }^{28}$ The first category, civil and political rights, include rights for life, freedom of religion or belief, freedom of speech and expression, and to participate in collective decision making (voting rights). It is all called the rights of a minimalist approach. Meanwhile the second category, the democratic rights, include rights for health, education, work and social security. These rights are

\footnotetext{
26Sandrine Baum, Hans Kelsen and The Case for Democracy, (ECPR Press, 2012), 35.

${ }^{27}$ See the latest amendment of Constitution of 1945

28Yudi Latif, Negara Paripurna: Historisitas, Rasionalitas dan Aktualitas Pancasila (Jakarta: PT. Gramedia Pustaka Utama, 2012),. 190-193.
} 
integration between civil rights and political rights. The third category, the economic-social-cultural and collective rights, include environmental protection of indigenous rights, economic and development, self-determination and so on.

Additionally, Kaelan ${ }^{29}$ describes similar rights including the rights for life, personal freedom, property, freedom of conscience and religion, freedom to have and express thought, freedom to assemble and convene, as well as to work and to receive humanistic treatment. In relation to freedom of religion, Carillo de Albornoz, as Koshy ${ }^{30}$ quoted, mentioned that religious liberty or freedom of religion has four main aspects namely liberty of conscience, liberty of religious expression, liberty of religious association, and liberty of religious institutionalization.

In the same context, Said Agil Husin Al Munawar ${ }^{31}$ explains that every citizen has the same rights and obligations. Citizens' rights should be preserved and respected, while liabilities are charged to them and the state must pay attention to the human factor with all of their powers and abilities. Human rights in society and nation therefore includes: freedom of religion, of education and teaching, of thought both orally and writing, of having a house or place of residence, of association and assembly, the rights on protection and legal equality, equality of constitutional rights, protection of self and property, individual freedom which the state cannot contested it, and rights to have equal position in the government. According to him, both majority and minority have the same rights and obligations as citizens and there should be no preferred and discriminated group. To conclude, it appears that the right for marriage is fundamental for citizens as it is a part of civil rights that the state is supposed to guarantee it.

\section{The Regulation on Interreligious Marriage in Indonsia}

According to Marriage Law No. 1 of 1974, "marriage is a physically and mentally bond between a man and a woman as

${ }^{29}$ Kaelan, Negara Pancasila,. 390.

${ }^{30}$ Ninan Koshy, Religious Freedom in Changing World (Geneva: WCC Publication, 1992),. 22.

31Said Agil Husin Al-Munawar, Figh Hubungan Antar Agama (Jakarta: Ciputat Press, 2005),. 35-36. 
husband and wife with intention of building a family or household that is happy and eternal based on the Divinity of the One God".

Marriage in Indonesia, before the birth of Marriage Law No. 1 of 1974, was regulated in several laws namely religious law, customary law and the West law. During the reign of the Netherlands, marriage was arranged in some rules according to the following grouping. First, Europeans followed the Civil Code (Burgerlijk Wetboek/BW). Second, Chinese in general also followed BW with the exception of the Civil Registration and the events before marriage. Third, Arabs and Orientals outside Chinese followed their own customary law. Fourth, indigenous Indonesian followed customary law in which Christians followed Marriage Act of Christian, Java, Minahasa and Ambon (Huwelijk Ordinance Christen Indonesiers Java, Minahasa an Amboina / HOCI) based on Staatsblad No. 74 of 1933. Fifth, people who belong to none of the previous classes/groups followed mixed marriage rules. ${ }^{32}$

The provisions of mixed marriage were stipulated in Staatsblad 1898 No. 158. Its first chapter mentioned that "mixed marriages are marriages between people in Indonesia which are under different laws". Thus, mixed marriages are between two persons who are in Indonesia yet subjected to different laws including interreligious marriage as described in article 7 paragraph 2 that "differences of religion, race or origin are not an impediment to marriage."

However, the concept of mixed marriage contained in the Marriage Law No. 1 of 1974 has different coverage with Staatsblad 1898 No. 158. Article 64 of Marriage Law states that "what is meant by a mixed marriage in the Marriage Law No. 1 of 1974 is a marriage between two people in Indonesia which are subjected to different laws because of different nationalities in which one of the parties has Indonesian nationality".

As Subekti ${ }^{33}$ explains, the birth of the Marriage Law No. 1 of 1974 symbolized the beginning effort of government to create uniformity of marriage law and eliminate its diversity. However, he believes that the provisions of Marriage Law has not set uniformity as

\footnotetext{
${ }^{32}$ Wirjono Prodjodikoro as cited by Khoiruddin Nasution, Status Wanita di Asia Tenggara: Studi terhadap Perundang-undangan Perkawinan Muslim Kontemporer di Indonesia dan Malaysia (Jakarta: INIS, 2002), 41.

${ }^{33} \mathrm{R}$ Subekti, Ringkasan tentang Hukum Keluarga dan Hukum Waris (Jakarta: PT. Intermasa, 1990),. 2.
} 
stipulated in Article 66 on "closing provision" which states that "the rules contained in the Civil Code, the Marriage Ordinance for Christian People of Indonesia (Staatsblad 1933 No. 74) and Regulation of mixed marriage (Staatsblad 1898 No. 158) are no longer valid in so far as regulated in the Marriage Law No. 1 of 1974."

The article 66 of Marriage Law obviously opens the opportunity to interpret some provisions that have not been explicitly regulated such as interreligious marriage. Since it has not been regulated, as the opinion of $\mathrm{Bayu}^{34}$, the provisions relating to mixed marriages based on the religious difference still follow Staatsblad 1898 No. 158, arguing that there is no other provisions including Marriage Law No. 1 of 1974.

Concerning to this, Ratno Lukito ${ }^{35}$ claims that the exclusion of interreligious marriage in the Marriage Law No. 1 of 1974 is a legal vacuum condition. It turns out that a Supreme Court's verdict, using human rights considerations, accepted a petition of interreligious marriage filed by Andy Vonny and Andrianus Pertus Hendrik Nelwan. As described in the legal considerations, the Supreme Court accepted their petition on interreligious marriage considering the constitutional rights of all citizens described in Article 27 of the Constitution of 1945 that every citizen is equal before the law.

Therefore, before the provisions of marriage on Marriage Law No. 1 of 1974, interreligious marriage has had its legal legitimation based on Staatsblad 1898 no. 158. It is obvious that Marriage Law has no provision on interreligious marriage since the law itself just recognizes and only declares the legitimation of intrareligious marriage as stated on Article 2 paragraph (1). Therefore, it makes sense if some argue that old provision such as Staatsblad 1898 No. 158 still has its own legitimation to justify interreligious marriage in Indonesia.

A problem emerges when the validity of a marriage as stated on article 2, paragraph (1) of Marriage Law No. 1 of 1974 is contrasted to the administrative provisions of interreligious marriage in Law No. 23 of 2006 on Demographic Administration. At glance, it seems that the

\footnotetext{
${ }^{34}$ Interview with Bayu, a clerk deputy at Surakarta State Court on November 14, 2013.

${ }^{35}$ Ratno Lukito, Hukum Sakral dan Hukum Sekuler: Studi tentang Konflik dan Resolusi dalam Hukum di Indonesia (Jakarta: Pustaka Alvabet, 2008),. 433
} 
state allows interreligious marriage because it must be unregistered formally. However, unfortunately, interreligious marriage is only recognized as an administrative marriage registered in the Office of Population and Civil Registry instead of a marriage legitimized as a legally valid one though some religious understandings allow this type of marriage. ${ }^{36}$ It is obvius, therefore, that the regulations of interreligious marriage are separated from normative validity on the Marriage Law with administrative rules in the law No. 23 of 2006 on the demographic administration and this makes interreligious marriage often referred to as a civil marriage.

\section{Administration System and Its Mechanism towards Interreligious Marriage in Indonesia}

Law No. 23 of 2006 on Demographic Administration describes the systematic order of people's important events, one of which is the event of marriage mentioned in Article 8 and 9 in addition to Article 34 and 35 which clarify the provisions of marriage registration. Article 34 states as follows: (1) A valid marriage under the provisions of law must be reported by the resident to the official agency where the marriage takes place 60 (sixty) days on the latest from the date; (2) Based on the report referred to number (1), Civil Registry officer records it on Marriage Act's register and publishes its Quoted Marriage Act. Afterward, Article 35 states that "the marriage registration referred to in Article 34 shall also apply to: (a) marriage determined by the court.

It is obvious from the above explanation that the critical events including marriages of couples outside Moslem communities are listed in the Office of Population and Civil Registry as described in the Article 8 of Law No. 23 of 2006. However, the elucidation of Article 9 paragraph (1) letter $b$ mentions that the recording is performed after the civil records receives Court decision indicating that the person concerned has got a State Court's deicision.

Regarding to administrative registration in accordance with Indonesian Government Regulation No. 9 of 1975 on the

\footnotetext{
${ }^{36}$ As the permissibility of interreligious marriage in Confucianism, some Muslims also believe the same based on Surat al Maidah 5 that allows marriage between a Muslim and a woman of people of the book who keeps her dignity or those who strongly hold to the teachings of religion before Islam.
} 
implementation of Law No. 1 of 1974 on Marriage Article 2 which describes the marriage registration, Civil registry's tasks are as below:

(1) To register marriages of those who perform its settlement according to Islamic teaching before the Registrar Officer based on Law No. 32 of 1954 regarding the record of Marriage, Divorce and Refer.

(2) To register marriage of those who perform its settlement according to their religion or belief (other than Islam) before the Registrar of Marriage Officer at the Office of Civil Registry as meant by various legislation on marriagge registration.

Meanwhile, mechanism of interreligious marriage registry in Indonesia as well as the provisions of Article 21 of Marriage Law No. 1 of 1974 are as follow:

1) Should the officer of marriage registrar find prohibition against the marriage according to the law, then he/she will refuse to accept the petition.

2) In case of rejection, the registrar will give a written statement of refusal accompanied by refusal reasons based on the request of one party who wishes to enter into the marriage.

3) By getting a letter of rejection mentioned above, the parties whose marriage plan is rejected have rights to apply to the Court at the area in which the marriage registrar rejected their submission

4) The court will shortly examine the case and will provide decision whether to strengthen the refusal or give an order so that the marriage can take place.

5) This provision loses its power when the barriers causing the rejection disappear and as a consequence, the party who wants to get marriadge can repeat the notice of their intent

Furthermore, after the State Court accepts the applicant's request of interreligious marriage, the applicants may register their petition to the Office of Population and Civil Registration. 


\section{The Policies of Implementing Interreligious Marriage}

The implementation of interreligious marriage in Central Java, namely, Surakarta, Semarang and Jepara regency has different experience, especially in terms of providing legal license. This is mainly because different legal understanding of the law enforcers on interreligious marriage.

At Surakarta State Court, after the issuance of Marriage Law No. 1 of 1974, interreligious marriage was still prohibited. It recently changed after ratification of the Law No. 23 of 2006 in which the Court received totally 39 petitions of interreligious marriage from 2007 to 2013. The petition itself is firstly submitted when the applicants register the marriage to the Civil Registry Office. After the Office checks it, the applicant will typically get a rejection letter because of interreligious marriage prohibition based on the provisions of article 21 of Marriage Law No. 1 of $1974 .{ }^{37}$

The rejection letter from the Office of Civil Registry then becomes one of requirements for applying permission/license to the State Court. Furthermore, the Court examines the petition from either its formal or material requirements namely compliance with requirements, reason on the applicant and the spouse's will to build interreligious marriage, and explanation of witnesses from each family to ensure that both parents have allowed and approved their marriage plan. At first, the judge always advises the couples to get marriage with those with same religion by explaining the risks of interreligious one. However, if a couple has already had strong willingness to perform interreligious marriage, the judge can order a new examination to continue. 38

Above statement is in line with description from Djoko (a subject of interreligious marriage and the first person to apply for interreligious marriage in 2007). In the process of his examination, the judge suggested him and SR (his wife) to marry under one religion

\footnotetext{
${ }^{37}$ Interview with Ms. EST, an officer who handled Interreligious Marriage Registration at the Office of Population and Civil Registration of Surakarta, dated 21 November 2013. Interview with Mr. Pramono, employees of the Civil Registry on November 14, 2013.

${ }^{38}$ Interview with judge Abdul Rohim of Surakarta State Court dated November 21, 2013. ABDR is also a judge who often deals with license application of interreligious marriage.
} 
but both insisted to perform an interreligious marriage because both had studied the legal provisions of interreligious marriage from Law of Marriage and Law of Demographic Administration. The judge eventually explained the risks they might endure if the interreligious marriage took place. After examining the evidence and witnesses while inviting some expert's witnesses from Islam and Christian's section of Religious Ministry Affairs of Surakarta, the judge issued law consideration and eventually granted a license for the interreligious marriage. Thus, Djoko mentions that his marriage is only civil marriage instead of a religious one. ${ }^{39}$

However, when there found a lack of one of the conditions, the license application of interreligious marriage will not be granted. This happened to a case of petition submitted by LNW to Surakarta State Court with Number of Registration: 375 / Pdt.P / 2013 / PN. Ska. The Court refused his petition by reasoning that there was one incomplete requirement namely a rejection letter from the Office of Civil Registry. However, after LNW filed again and fulfilled its missed requirement, finally the Court granted him license of interreligious marriage at the Decision of Surakarta State Court No. 408 / Pdt.P / 2013 / PN. Ska.

Shortly after the provisions of Law No. 23 of 2006 on the Demographic administration ratified, from 2007 to 2013, all applications for interreligious marriage licenses submitted to the State Court of Surakarta were granted but one as mentioned before. Besides, there was a petition filed twice since its first submission was withdrawn by the applicant and graned on Decision of Surakarta State Court No. 65 / Pdt / 2012 / PN.Ska about revocation. However, after the applicant filed back and fulfilled all terms and conditions, the request was granted on the Decision of Surakarta State Court No. 237 / Pdt.P / 2012 / PN.Ska.

Besides fulfilling all terms and conditions, all application petitions was granted because the judge has discretion to enforce the law and provide legal remedies for the applicants. ${ }^{40}$ Judge Ely ${ }^{41}$ who granted some requests for interreligious marriage, for example, had

${ }^{39}$ Djoko is the first person to apply for interreligious marriage in the Surakarta State Court after Law No. 23 of 2006. It resulted the Decision of Surakarta State Court No. 111 / Pdt.P / 2007 / PN.Ska

${ }^{40 I n t e r v i e w ~ w i t h ~ J u d g e ~ A b d u l ~ R o h i m, ~ S u r a k a r t a ~ S t a t e ~ C o u r t ~ o n ~ N o v e m b e r ~ 21, ~} 2013$.

41Interview with judge Ely, Surakarta State Court on November 21, 2013. 
some formal and material reasons such as: 1) as a legal protection for couples who want to get marriage and remain in their own religion, 2) for avoiding bad things to happen; 3) considering that getting marriage is the rights of every citizen. According to him, when the state legalizes marriages in overseas as the provisions of Article 56 paragraph (1) of Law No. 1 of 1974, the state actually makes legal dualism since Indonesia has its own regulations.

Additionally, in Surakarta, the role of religious leaders serve only as secondary, namely someone who offers religious guidance for prospective couples such as when they give statement as experts witness in Court's determination No. 65 / Pdt / 2012 / PN.Ska. ${ }^{42}$

The policy on interreligious marriage in Surakarta is different from those in Semarang and Jepara. In these two last cities, legal interreligious marriage has no opportunity to perform and this signifies that the State Court of Jepara and Semarang only interpret the validity of marriage based on the provisions of Marriage Law No. 1 of 1974 that it must be between the couples of one religion. As a result, this understanding suggests them not to receive any license application of interreligious marriage. Judge ST said that it is impossible to receive such application if the incoming request is not scheduled or rejected by the young clerks who rely their argument on Book II of the Code of Duties and Court Administration, Article 12 of the Case Request, especially Articles 12 and 13. It mainly states that the determination also cannot be accepted in lights of the request to certify that a document/act is legitimate". 43

The policy of Semarang State Court to reject the interreligious marriage implies that it does not consider the provisions of article 21 of the Marriage Law No. 1 of 1974 explaining that the concept of marriage should accomodate the perception of the judge and some prohibitions. In such conditions, interreligious couples who want to perform marriage in Semarang should convert into his/her couple's religion for the sake of validity of their marriage. They must decide which spouse should temporarily convert his/her previous belief into their spouse's religion by changing religious identity on their identity

\footnotetext{
${ }^{42}$ See the excerpt of Surakarta State Court Decision No. 65/Pdt/2012/PN.Ska 43Interview with ST, a judge of Civil Code at Semarang State Court on November 27, 2013.
} 
cards (Kartu Tanda Penduduk/KTP) to comply with the marriage administration. After the marriage gets legalization, they turn their religion back into their own original teachings and religious rituals. This, for instance, happened to a couple of SR who is a Muslim woman and her husband STF who is a Catholics. SR converted into her husband's religion and performed a marriage using Catholicism way. After the marriage, however, SR continued to perform her Islamic rituals. ${ }^{4}$ The same is the case of SHD, a Catholics who converted into Islam when he wanted to marry MSY who is a Muslim woman. After the marriage settlement, he converted back into his Catholicism and until now both have had three children. ${ }^{45}$

Nevertheless, the Civil Registry Office of Semarang actually understands that registration procedures of interreligious marriage was stipulated in Law No. 23 of 2006. Unfortunately, as SRI ${ }^{46}$ said, from 2008 to 2013, the Civil Registry only recorded one case of interreligious marriage dated on 27 February 2010, No. 3374.PK.2010.00204. SRI conceded that it was granted based on the decision given by the State Court of Tanjungkarang, No. 11 / Pdt.P / 2010 / PN.TK. dated on February 15, 2010.

The same thing happens in Jepara. Although a lot of interreligious marriage settlement has been performed, there found at least three models to classify.

First is a category in which one party either temporarily or permanently converts to his/her spouse's religion so that they perform their marriage following the chosen one. It is, for instance, done by; 1) JD, a Muslim who converted to Buddhism before marrying JM, a female Buddhist,47 2) SMI, a Muslim who converted to Buddhism for the benefit of marriage with SDI, a Buddhist, 3) JV, a Muslim-turned Buddhist shortly before settling marriage with AND,

\footnotetext{
${ }^{44}$ Interview with SR at her house, Jangli Perbalan Timur Street, No. IV/127-A RT. 06 RW. 06 Ngesrep, Banyumanik, Semarang City on November 15, 2013.

45Interview with MSY at her house, Jatiluhur Timur Street, No. VIII/320 RT. 01 RW. 05 Ngesrep, Banyumanik, Semarang City on November 16, 2013.

${ }^{46}$ Interview with SRI, the section head of Marriage and Divorce at Office of Population and Civil Registry of Semarang City on November 28, 2013

47The case of religious submission prior to the marriage was told by a Buddhist monk who is a member of RAS FKUB Jepara on November 20, 2015.
} 
a Buddhist, and 4) RJT, a Muslim who converted to Hindu to marry a Hindus, LS. 48

Second is a category in which each party follows the procedures of each respective religion so that the performed marriage settlement programs use both religious teachings and rituals. It is, for instance, done by YS, a Catholics who married SF, a Muslim. Both got married with two religious ordinances of Islam and Catholicism then registered it at the Civil Registry Office under Chatolicism. ${ }^{49}$

In this category, religious leaders only play a role to provide religious solution for couples who want to perform an interreligious marriage. However, along with validity which happens twice (from each other religion), this kind of marriage normatively becomes a problem although it becomes the best solution because the couple feel it most suitable with their respective religions on the other hand. For the administrative side, they usually register their marriages by following one religious requirements only.

Third is a category which uses a preferred (other) religion out of their own religion based on their agreement. For instance, it happened to a marriage of a Chinese man with a Muslim woman whose license application of interreligious marriage was rejected by the Court. They finally chose a marriage based on Christianity 50 because Chinese religion had just been recognized as an official religion in Indonesia since the presidency of Gus Dur in 2000. Whereas in Islam itself, interreligious marriage is normatively not allowed as stated on the Fatwa (decree) of Indonesian Ulema Council and Islamic Law Compilation. ${ }^{51}$ Choosing new religion therefore became logical solution as a middle way deemed to be the most convenient one.

\footnotetext{
48See the evidence of statement letter written by RJT on the stamp Rp. 6000,-. It states that: Declare truthfully and with sincerity, without coaxing, I convert to the Hinduism. I make this statement in a healthy state of mind without any influence from any party. In doing so, the letter I made is to be used properly.

${ }^{49}$ Interview with a subject of interreligious marriage, YS on November 18, 2013

${ }^{50 I n t e r v i e w ~ w i t h ~ U t o, ~ a ~ c l e r k ~ o f ~ J e p a r a ~ S t a t e ~ C o u r t ~ o n ~ N o v e m b e r ~ 18, ~ 2013 . ~ U t o m o ~ i s ~}$ also a witness to the marriage of a Chinese man and a Muslim woman who had trouble because the policy did not support, and eventually they got married in a Christian way.

51The Decision of the 2nd National Conference of Indonesian Ulema Council in Jakarta on May 26, to June 1, 1980 which was amended by Fatwa of Indonesian Ulema Council No. 4 / Munas VII / MUI / 8/2005 stipulated at the 7th National Conference
} 
In short words, interreligious marriage in Jepara have never formally happened since the law enforcers just follow the Article 21 of Law No. 1 of 1974 which states that a marriage must go through the application for a license from the State Court and be subsequently registered in the Civil Registry Office. However, there exist three models of interreligious marriages as mentioned above.

Such conditions happen because the Court gives no opportunity for the parties to request a license for their interreligious marriage as the procedure stated on Article 21 of the Law of Marriage No. 1 of 1974. The Court has its own principle that marriage must be performed by a man and a woman who believe the same religion. It means that the Court just considers the provision of marriage from the aspect of its validity written in Article 2 paragraph (1) Law of Marriage No. 1 of 1974.

Thus, in addition to their own interests, the policy to implement interreligious marriage is strongly influenced by how and to what extent the stakeholders understand or consider the provisions on interreligious marriage. In this view, Mahfudh argues that state policies do affect the color of any existing law. ${ }^{22}$ Similarly, Birkland 53 explains that among its characteristics, policy is created based on public interests.

To sum, serving as policy makers, all stakeholders agree that legal validity of marriage in Indonesia has been set in Marriage Law No. 1 of 1974 . However, the breadth of views and belief of each greatly affects their understanding on provisions of interreligious marriage. Not only be it contained in the provisions of article 2, paragraph (1) Marriage Act No. 1 in 1974, its procedures are also explained in Article 21 of the Marriage Law No. 1 of 1974 concerning the legal order of interreligious marriage, the provisions of Staatsblad No. 158 of 1898 and Law No. 23 of 2006 on Demographic

in 2005. See also the provisions of Article 40 and 44 Compilation of Islamic Law that becomes one of the material sources of Islamic law in Indonesia.

${ }^{52}$ Moh. Mahfudh MD, Membangun Politik Hukum, Menegakkain Konstitusi (Jakarta: Rajawali Press, 2011),. 5. See also Klein as cited by Adang Yesmil Anwar, Pembaruan Hukum pidana; Reformasi Hukum (Jakarta: Grasindo, 2008),. 57.

53Thomas A. Birkland, Introduction to the Policy Procces; Theory, Concepts and Models of Public Policy Making (New York: M.E. Sharpe. Inc, No. 3, 2011),. 8-9 
administration including administration system of interreligious marriage.

On the other hand, opinion on interreligious marriage law provisions in Surakarta, Semarang and Jepara among informants of this research is as follows.

First is opinion that interreligious marriage is not regulated in the Marriage Law No. 1 of 1974 because it only regulates the same religion's marriage as defined in Article 2 paragraph (1) stating that "a marriage is valid when its settlement is performed according to the law of each religion and belief". In addition, the provision of Article 66 on Marriage Law is understood as the one which replaced the provisions on mixed marriages in the Staatsblad 1898 No. 158. For them, therefore, these provisions indicate that the state requires marriages between men and women of the same religion. Thus, an interreligious marriage is not valid. Among the informants who believe this opinion are the stakeholders in the Semarang and Jepara State Court.

Second is opinion that Article 2, paragraph (1) of Marriage Law has described the validity of marriage in Indonesia while considering what Article 66 of Marriage Law mentions that regulations in the Civil Code, the Marriage Ordinance for Christians in Indonesia (Staatsblad 1933 No. 74) and Mixed Marriages Regulation (Staatsblad 1898 No. 158) are no longer valid because it was renewed by the Marriage Law No. 1 of 1974 itself. Therefore, it further infers that interreligious marriage metioned in the Staatsblad 158 of 1898 is still valid simply because it is not clearly regulated in the Marriage Law No. 1 of 1974. Thus, in accordance with Article 66 and interpretation that interreligious marriage is included at the Law no. 1, it becomes valid right away. Similarly, the provision of Article 56 of the Marriage Law No. 1 of 1974 describes the possibility of Indonesian citizens to get married in overseas which as long as they comply with foreign rules where the marriage settlement takes place. As a result, it provides an opportunity for Indonesian people, especially for couples of different religions, to get marriadge in another country that allows religious marriage then go back to Indonesia to legalize it.

This opinion also relies on the administration system of marriage regulation among interreligious couples in Article 35 of Law No. 23 of 2006 stating that: "The marriage registration also applies to: 
(a) marriages determined by the Court". Additionally, there exist another administrative provision on registering interreligious which was preceeded by legal license on interreligious marriage issued by the State Court in Article 21 of Law No. 1 of 1974. Among the informants who support this opinion are some judges in Surakarta State Courta and some officers at Surakarta, Semarang and Jepara Civil Registry Office.

In a bigger picture, the rule of interreligious marriage in Marriage Law is really ambiguous. In one hand, Article 2 paragraph (1) Marriage Law clearly states as follows: "marriage is lawful in accordance with our religion and belief." On the other hand, however, Article 21 outlines some steps a couple whose marriage is prohibited needs to do. Although there found no explicit explanation that the ban applies, among others for interreligious marriadge, each religion normatively considers the prohibition of interreligious marriage.

Normatively, the stakeholders understand that Article 2 paragraph (1) of Law No. 1 of 1974 orders the state to only legalize the same religion marriage. Some respective religious leaders, however, have different opinions on this issue in which some of them interprets that a marriage has to perform with couples of the same religion while some others interprets that a marriage can be valid between couples of different religions.

Some Islamic scholars who wrote the book Figh Lintas Agama (Interreligious Figh) such as Nurcholish Madjid, Komarudin Hidayat and Musdah Mulia, for instance, are a part of the second category. They believe that prohibition of interreligious marriage at the era of caliphate Umar was for political reasons instead of ideological. Therefore, according to them, interreligious marriage is actually allowed. ${ }^{54}$

Similarly, Catholicism, Christianity, Buddhism, Hinduism and Confucianism also have their own opinions. In Catholicism, for example, a Catholics is allowed to get married to a spouse from another religion as long as they both have been baptized and have promised to avoid polygamy or divorce during their marriage life. Furthermore, the signing of the marital form which has been

\footnotetext{
${ }^{54}$ Mun'im A. Sirry (Ed.) Fikih Lintas Agama; Membangun Masyarakat Inklusif-Pluralis (Jakarta: Paramadina, 2004),. 163
} 
preprared will be attached to the permit application/dispensation. In this case, the non-Catholics spouse is asked to sign under the status of "knowing." However on educating children, the Church asks a Catholic spouse to do their utmost in Catholic way and try to baptize them. 55

Meanwhile in Christianity, interreligious marriage must qualify some following requirements: a) the approval of both prospective couples, b) each bride or groom has no marital relationship with another person, c) the minimun requirement that at least, one of both is Protestant, d) the minimun requirement that at least, one of both is a member of the Church in which a mixed marriage settlement can take place while another one (a non-Protestant spuose) makes a statement that he/she has no objection to perform his/her marriage settlement in a Protestant church. ${ }^{56}$

Likewise, in Buddhism, interreligious marriage is also allowed according to the decision of the Supreme Sangha Indonesia as long as the marriage ratification is done in Buddhism way. In this case, a nonBuddhist bride/groom is not required to firstly convert to Buddhism. However at the marriage settlement, as a part of its rituals, he/she is required to say "in the name of the Buddha, Dharma and Sangha" which are the Gods of a Buddhist.

The same way goes on in the modern Hinduism. A Hindush reformer, Swami Vivekananda in India, pioneered very tolerant and contextual way of thinking that allows a Hindu to marry non-Hindus as long as it fits with so called asmastuti (the deepest heart). This furthermore closely relates to other terms known as Istadevata, namely the freedom to worship God in the most suitable way and Adikara which means the freedom to praise God in a way that suits us. ${ }^{57}$ Likewise, in Confucianism, a Prophet of Confucianism, Prophet Kongzi, also states that interreligious marriage is not prohibited as long as there exist important harmony between heaven and earth, or men and women who get married. ${ }^{58}$

\footnotetext{
${ }^{55}$ R. Hardawiryana, S.J., Dokumentasi dan Penerangan KWI (Jakarta: Obor, 1993), 309316

56Asmin, Status Perkawinan Antar Agama (Jakarta: PT. Dian Rakyat, 1986),. 41

57See Ahmad Baso and Ahmad Nurcholis (Eds.) Pernikahan Beda Agama: Kesaksian, Argumen Keagamaan dan Analisis Kebijakan, (Komnas HAM dan ICRP, 2005),. 213-215.

${ }^{58}$ Ahmad Baso and Ahmad Nurcholis (Eds.) Pernikahan Beda Agama,. 216-218
} 
In addition to religious interpretations, another problem of interreligious marriage is when contrasted to articles explaining that the rights of citizens to get marriage is a basic right and recognized in Indonesian constitution, namely Article 28B of the 1945 Constitution. It states that "everyone has the rights to build a family and continue the descendants through legitimate marriage". Other than that, Article $28 \mathrm{E}$ states that "everyone is free to believe in religion and to worship according to their religion ...". Furthermore, Article 29 paragraph (2) states that "the state guarantees the freedom of every citizen to profess their own religion." 59

Thus, the different policies due to different legal interpretation of the law are a daily life problem, particularly in Semarang and Jepara. When a State Court rejects to permit interreligious marriage, it shows that its policy makers do not follow the order of law stated on Article 21 of the Marriage Law No. 1 of 1974. In fact, the Article 29 paragraph (2) of the Constitution of 1945 has mandated the policy makers to enforce justice in society, because society, as citizen, has the same rights to worship according to their own religion or belief.

Therefore, the policy makers should have broader understanding about the regulations of interreligious marriage so that they can provide a fair solution to the whole community including couples who want to perform interreligious marriage. In addition, laws on marriage should not contradict each other and have a chance to create different understanding starting from the rules in Pancasila as the state ideology, the Constituion of 1945, the Marriage Law No. 1 of 1974, the Demographic Administration Law No. 23 of 2006 and others.

\section{Interreligious Marriage: Between State Policy and Rights of Civil Society}

A state, according to Rawls' concept, should ideally give a sense of justice for its people not only in normative level but also in the procedural ones. Thus, when the freedom to practice religion has been normatively specified in the Indonesian constitutional law, namely Article 29 of the Constitution of 1945, the issue of interreligious marriage should have been regulated in detail in Marriage Law No. 1

\footnotetext{
${ }^{59}$ See The Constitutional Court of the Republic of Indonesia.
} 
of 1974. Policies of state stakeholders then exacerbate this condition by considering uncomprehensive understanding on the provisions of interreligious marriage.

The reality in Semarang and Jepara implies that the chosen policies have not yet reached the level of normative justice and procedural fairness. It appears on how the normative understanding of interreligious marriage has not been combined and balanced with other provision, especially Article 2 paragraph (1), Article 21 and Article 66 of Marriage Law No. 1 of 1974. Similarly, there found no effort to correlate the issue of interreligious marriage with the context of religious freedom as enshrined in Article 29 of the Constitution of 1945. Seemingly, the policy makers have failed to acknowledge relevancy of some related provision.

In the process of implementing interreligious marriage policy, this normative and narrow point of view greatly affects the implementation of interreligious marriage policy. Rejection on the license application of the Court clerks obviously shows how the policy makers procedurally give no sense of justice to the citizens who apply for interreligious marriage. Because of such policy, the Office of Civil Registry automatically will not record the marriage because there is no permission from the State Court. In fact, each Civil Registry Office in Jepara and Semarang has recorded only one case of interreligious marriage with licenses granted by the State Court outside both regions.

It is clear, therefore, that the understanding of interreligious marriage in Indonesia should not only rely on an article only while ignoring other relevant ones. It needs a broader point of view beginning from understanding on the fifth precept of Pancasila,"social justice for all Indonesian people", the Constitution of 1945, to the provisions of the laws and its related rules.

In Surakarta, on the other hand, the stakeholders seem to be more just. The State Court of Surakarta always integrates the provisions of Article 66 of Marriage Law No. 1 of 1974 with the understanding that the abscence of interreligious marriage provisions in the Marriage Law actually makes the rules remain valid by using the provisions of Staatsblad 1898 No. 158. Surakart judges also like to consider Article 29 of the Constitution of 1945 which explains the freedom of every citizen to believe in faith on one God Almighty as 
their legal consideration. Besides that, the judges also take into consideration Article 8 (f) and Article 21 of the Marriage Law No. 1 of 1974.

Among others, such legal consideration can be found in the State Court Decision No. 90 / Pdt.P / 2011 / PN.Ska as follow:

1) Religious differences do not constitute a ban to build a marriage as mentioned at Article 8 (f) Marriage Law No. 1 of 1974 as well as Article 35 paragraph (a) of Law No. 23 of 2006 on Demographic administration which writes that the State Court has the authority to examine and decide on the issues of interreligious marriage;

2) A citizen has the rights to maintain his/her religious belief, including to build households with spouses of different religions in accordance with Article 29 of the Constitution of 1945 concerning the freedom to believe in faith on one God Almighty;

3) The Marriage Law No. 1 of 1974 Article 8 (f) governs the prohibition of marriage yet it does not explicitly regulate an interreligious marriage;

4) The Marriage Law No. 1 of 1974 Chapter XIV Article 66 states: "For marriage and everything related to marriage is based on this Law; therefore, by the enactment of this Law, the provisions stipulated in the Civil Code, HOCI Stbl. No. 74 of 1993 (Marriage Ordinance for Indonesian Christian), Mixed Marriage Regulation (Regeling op de gemengde Huwelijke Stbl No. 158 of 1898) and other regulations governing marriage as long as has been regulated in this Law, are declared to be invalid;

5) The No. 5 of general explanation of the Marriage Law No. 1 of 1974 says "to ensure legal certainty, the marriage and everything associated with it prior to the enactment of this law and is run according to the existing law, is considered valid. Similarly, if this law does not give any regulation on any specific thing, the existing provisions apply itself right away;

6) The Court considers that because the Marriage Law No. 1 of 1974 does not explicitly regulate an interreligious marriage in which the applicants insist on maintaining their religious beliefs, then the provisions of Stbl: 1898 No. 158 on the Rules of Mixed Marriage can be applied in the petition of the applicant; 
The above Surakarta State Court's understanding went the same with the officer of Surakarta Civil Registry Office. The Office follows the provisions of Law No. 23 of 2006 which governs provisions of marriage documentation for non-Moslem couples, including an interreligious marriage that has received permission from the State Court. Apart of law enforcer's understanding, the role of religious leaders in an interreligious marriage only functions to providing confidence for those couples. From reality, it seems that the normative and procedural justice at Rawls' concept are more visible to occur in the implementation of marriages in Surakarta.

The different policy overshadowed by different understanding on the provisions of interreligious marriage at the State Court and the Office of Civil Registry in Semarang, Jepara and Surakarta indicates the existence of different interpretation among the law enforcers of the relevant regulations in Indonesia. In fact, the policy makers and law enforcers should firstly understand the legal basis of Pancasila and the provision in Article 29 paragraph (2) of the Constitution of 1945 which states "the State guarantees the freedom of every citizen to profess their own religion", Law No. 39 of 1999 on Human Rights (HAM) Article 10, paragraph (1) which explains "every person has the right to build a family and continue their descendant through legitimate marriage and free will", as well as related articles on interreligious marriage which are not explicitly described in Marriage Law No. 1 of 1974.

This all aims to make the state provide a sense of justice for the benefit of its people in order to get legality of interreligious marriage. As Said Agil Husin Al Munawar60 explains, the citizen has the same rights and obligations to be maintained and respected by the state and other citizens. Similarly, the state has obligation to promote and realize the Rawlsian justice which does not only involve normative thing, but also relates to justice called distributive or procedural justice.

60Said Agil Husin Al-Munawar, Fiqh Hubungan Antar Agama (Jakarta: Ciputat Press, 2005),. 35-36. 


\section{Conclusion}

The implementation of interreligious marriage in Central Java is different from one region to another. In Surakarta, the implementation begins when a couple from different religion applies for registering interreligious marriage to the Civil Registry Office. The Office then provides a rejection letter as the basis for the couple to apply for interreligious marriage license to the State Court. After the Court granted license to perform the marriage, then the Civil Registry Office will record that interreligious marriage.

It is different from what happens in Semarang and Jepara. In Semarang, interreligious couples cannot perform any marriage settlement and it has forced a temporarily religious subjugation of one spouse to his/her couple's religion for the sake of a legalized marriage. Jepara also experiences the same, even there is a model of interreligious marriage performed in two religious rituas, although they only register one religious marriage to the government. There also occurs a model of marriage that does not follow the religion of husband or wife; they choose another religion (outside what they both believe) and rituals they deem as the most convenient one. Conclusively, in addition to the different interpretation to the rules of interreligious marriages in Indonesia, those interreligious marriage policies closely relate to the religious understanding of its policy makers and law enforcers.

\section{Bibliography}

\section{Book and Articles:}

Al-Munawar, Said Agil Husin, Figh Hubungan Antar Agama, Jakarta: Ciputat Press, 2005.

Anwar, Adang Yesmil, Pembaruan Hukum Pidana; Reformasi Hukum, Jakarta: Grasindo, 2008.

Asmin, Status Perkawinan Antar Agama. Jakarta: PT. Dian Rakyat, 1986.

Baso, Ahmad dan Ahmad Nurcholis (Eds.) Pernikahan Beda Agama: Kesaksian, Argumen Keagamaan dan Analisis Kbijakan, Komnas HAM dan ICRP, 2005.

Birkland, Thomas A., Introduction to the Policy Procces; Theory, Concepts and Models of Public Policy Making, New York: M.E. Sharpe. Inc, cet.3, 2011. 
Cammack, Mark, Legal Aspect of Muslim-Non Muslim Marriage in Indonesia, in Gavin Willis et.al (Ed.) Muslim-Non Muslim Marriage: Political and Cultural Contestation in Southeast Asia, Singapore: Iseas Publishing, 2009.

Dery, David, Problem Definition in Policy Analiysis, Kansas: University Press of Kansas, 1984.

Foucoult, Michael, Society Must be Defended, New York: Martin Press, 2003.

Hardawiryana, S.J, R., Dokumentasi dan Penerangan KWI, Jakarta: Obor, 1993.

Hariyanto, Erie, Muhammad Taufiq, Abidin Zainal, Ulum Miftahul, and Maimun Maimun. "Effectiveness of the Economic System to Zakat and Waqf for Empowerment of the Ummah in Indonesia." International Journal of Advanced Science and Technology 29, no. 06 (2020)

Koshy, Ninan, Religious Freedom in Changing World, Geneva: WCC Publication, 1992.

Latif, Yudi, Negara Paripurna: Historisitas, Rasionalitas dan Aktualitas Pancasila, Jakarta: PT. Gramedia Pustaka Utama, 2012.

Liddle, R. William, Soeharto's Indonesia; Personal Rule and Political Institutions, dalam Pacific Affairs, Vol. 58, No. 1 (Spring, 1985).

Lukito, Ratno, Hukum Sakral dan Hukum Sekuler: Studi tentang Konflik dan Resolusi dalam Hukum di Indonesia, Jakarta: Pustaka Alvabet, 2008.

Mahfudh MD, Moh. Pergulatan Politik dan Hukum di Indonesia, Jogyakarta: Gama Media, 1999.

Mahfudh MD, Moh., Membangun Politik Hukum, Menegakkan Konstitusi, Jakarta: Rajawali Press, 2011.

Nasution, Khoiruddin, Status Wanita di Asia Tenggara: Studi terhadap Perundang-undangan Perkawinan Muslim Kontemporer di Indonesia dan Malaysia, Jakarta: INIS, 2002.

Rawls, John, A Theory of Justice, The Theory of Justice, United States of America: Harvard University Press, 2003.

Sirry, Mun'im A. (Ed.) Fikih Lintas Agama; Membangun Masyarakat Inklusif-Pluralis, Jakarta: Paramadina, 2004.

Subekti, R, Ringkasan tentang Hukum Keluarga dan Hukum Waris, Jakarta: PT. Intermasa, 1990. 
Wahid, Marzuki dan Rumadi, Figh Madzhab Negara Kritik atas Politik Hukum Islam di Indonesia, Yogyakarta: LKiS, 2001.

\section{Regulations}

Constitutional Court of Republic of Indonesia, Undang-Undang Dasar Negara Republik Indonesia tahun 1945 dan Undang-Undang Republik Indonesia Nomor 24 Tahun 2003 tentang Mahkamah Konstitusi sebagaimana telah diubah dengan Undang-Undang Nomor 8 Tahun 2011 tentang Perubahan atas Undang-undang Nomor 24 Tahun 2003 tentang Mahkamah Konstitusi, Jakarta: Sekretariat Jenderal dan Kepaniteraan Mahkamah Konstitusi Republik Indonesia, 2011. Law No. 1 of 1974 on Marriage

Law No. 23 of 2006 on Demographic Administration

Law No. 39 of 1999 on Human Rights

Inpres No. 1 of 1991 on Islamic Law Compilation Book I on Marriage Presidential Instruction No.14 of 1967 on State-Recognized Religons

Decree of Ministry of Home Affairs of 1978.

Presidential Decree No. 6 of 2000 on State-Recognized Religons

Presidential Decree No. 1 of 1965 on State-Recognized Religons

Decision of Judicial Review on Law No. 1 of 1974 on Marriage against Constitution of 1945, No. 68/PUU-XII/ 2014

Decision of Supreme Court No. 1400 K/PDT/1986

Fatwa of Indonesian Ulema Council No. 4/Munas VII/MUI/8/2005

Stipulation of Surakarta State Court No. 65/Pdt/2012/PN.Ska 